\title{
David in History and in the Hebrew Bible
}

\author{
Łukasz Niesiotowski-Spanò
}

David, next to Moses, is one of the most studied biblical characters. ${ }^{1}$ The problem is, however, that this important figure has no clear extra-biblical reference, which makes reconstructing the historical David and his kingdom a difficult, if not an impossible, task. A short paper such as this cannot exhaustively examine scholarly literature on David, nor every mention of the son of Jesse in biblical literature. Therefore, this article's objective is solely to review extra-biblical sources, as well as selected biblical traditions related to this figure, to see whether at all, and if so, to what extent, they can be considered reliable historical sources, and on this basis to offer some general observations on the historical David.

The name "David" ( $d w d / d w y d)$ is not common in West-Semitic onomastics. In the Hebrew Bible, it describes a single figure. The form dāwid/dāwìd is usually derived from the root $d w d$, meaning "to love" or "to be beloved," which is also used to denote the uncle-family relation: "uncle" - dōd; "aunt" - do $d \bar{a} .^{2}$ Incidentally, it may be observed that despite numerous studies, it remains uncertain whether the noun $d \bar{u} d$, meaning "pot" or "jar"3 (cf., e.g., 1 Samuel 2:14), is related to the same root and its semantic field. Be that as it may, the names of a few other biblical characters are also derived from the same Hebrew root $d w d$ :

- $d \bar{o} d \bar{o}$ (Judges 10:1; 2 Samuel 23:9. 24; 1 Chronicles 11:12. 26; 27:4);4

- dōday (1 Chronicles 27:4);

- dōdāwāhū - for dōdiyāhū (2 Chronicles 20:37). ${ }^{5}$

1 The paper was prepared within the framework of the research project, "The Second Temple Jews - Between Tradition and the Greek World. The Greek Impact on the Second Temple Jews and its Dynamics," (2016/23/в/HS3/01880), sponsored by the National Science Centre - Poland.

2 See $B D B$, s.v.

3 See Noonan, Non-Semitic Loanwords, 328-329.

4 See Schley, "Dodo (person)."

5 See Dempster, "Dodavahu (person)."

(C) ŁUKASZ NIESIOŁOWSKI-SPANÒ, 2021 | DOI:10.1163/9789004465978_003

This is an open access chapter distributed under the terms of the CC BY-NC 4 - pilicense. 
The etymology of the name "David," or rather its atypical form, compelled scholars to look for parallels in the Ancient Near East. One of them, often cited in scholarly literature, is the Akkadian word dawìdüm, known from the Mari archive. This term was interpreted as the name of a military official of unknown rank, possibly a military leader. ${ }^{6}$ However, this interpretation of the texts from Mari turned out to be inaccurate. ${ }^{7}$ Most scholars addressing the subject opt for the reading that links the term dawidūm with the verb dabdu - "to defeat" (CAD, D, 14-16) - which is unrelated to the Hebrew root $d w d . .^{8}$ This etymology of the Akkadian word makes any effort to trace the etymology of the name "David" to the term for a military leader unfounded.

Apparently, the hypothesis that links the Hebrew name "David" with the word attested to in line 12 of the Mesha stele inscription, $d w d$ (as: $d w d h)\left(K A I^{2}\right.$ 310; ANET 320-321; $\operatorname{CoS} 2,137-138$ ), is much more solid. Klaas Smelik translates this line as follows: "I brought back the fire-hearth of his Uncle(?) from there," interpreting the word $d w d h$ as the title of god whose sanctuary in Atharoth is referred to in the text. ${ }^{9}$ Thomas L. Thompson, ${ }^{10}$ as well as Kenneth Kitchen, ${ }^{11}$ opt for the same interpretation of the enigmatic word in line 12. In addition, some scholars interpret the term $d w d$ as the proper name of a deity. ${ }^{12}$ The interpretation of the word $d w d$ in line 12 of the Mesha stele as a divine epithet, related to the main meaning of the root, i.e., "beloved one," prevails in recent scholarship. ${ }^{13}$

Scholars also proposed translating the term $d w d h$ in the Mesha stele inscription as a title of a person related to the local sanctuary in Atharoth. ${ }^{14}$ Despite the fact that such an understanding of this term fits the context well, it is impossible to determine its exact meaning on the basis of its etymology. This interpretation might be supported by 1 Samuel 10:14-15, where the term $d \bar{o} d$ describes a person. Most biblical translations render $d \bar{o} d$ in this verse as "uncle," which, given the context, is not fully convincing. The uncertainties

6 Cf. Thompson, The Bible in History, 204-205.

7 See Tadmor, "Historical Implications."

8 Cf. Howard, "David (person)."

9 See $\operatorname{CoS}$, vol. 2, 137, n. 12.

10 See Thompson, The Bible in History, 204-205.

11 See Kitchen, On the Reliability of the Old Testament, 452-453.

12 See Barstad, "Dod."

13 See Jackson "The Language of the Mesha Inscription," 112 where word $d w d$ in line 12 is not translated: "After one hundred years of study directed at the M[esha] I[nscription], it is safe to say that an exact understanding of these words is still a mystery." See also Mykytiuk, Identifying Biblical Persons, 121-126. Cf. $d d$ - "loved one" in Ugaritic, in Del Olmo Lete and Sanmartín, A Dictionary, 264-265, sv. dd.

See $D N W S I$, vol. 1, 242-243. 
have led scholars to propose other possible meanings for this term on a contextual basis, e.g., as referring to a certain military functionary..$^{15}$ As demonstrated above, such a reading does not shed much light on the etymology and origins of the biblical David's name. ${ }^{16}$

In the quest for extra-biblical data supporting the historicity of the biblical David, scholars cite cases in which the name "David" is used to refer to the founder of a ruling house. Even though such sources do not directly attest to David's historicity, they provide unique evidence of the existence of an ancient tradition related to David as the founder of a dynasty in Judah.

The first evidence of this sort comes from a stele excavated in Tel Dan. ${ }^{17}$ The Aramaic inscription on it, dated to the ninth century вСЕ, bears an expression in line 9: bytdwd ( $\left.\mathrm{KAI}^{2} 310 ; \mathrm{COS}, 2,161-162\right) .{ }^{18}$ The most obvious reading of it is "House of David." It is little wonder, therefore, that it has often been used as an argument to prove the historical existence of the biblical David. However, some scholars have expressed doubts about the inscription's authenticity. ${ }^{19}$

Doubts also arose with regard to the well-known Mesha stele's Moabite inscription, dated to the ninth century вСЕ, when André Lemaire suggested the reading of $b t[d] w d$ in line 31 as "House of David."20 Given that his reading is uncertain, it has not been universally accepted. ${ }^{21}$

In 2019, Israel Finkelstein, Nadav Na'aman and Thomas Römer published an article challenging Lemaire's interpretation..$^{22}$ They argue that there is no basis for reading $b t[d] w d$ in line 31 of the Mesha stele as "House of David," and contend that the geographical context suggests that the reconstructed name should be of a Moabite ruler. Such an interpretation renders Lemaire's reading unsustainable. The analysis of new photographs of the inscription and the squeeze of the stele prepared before its stone was broken led Finkelstein, Na'aman and Römer to conclude that the $b t d w d$ reading should be excluded.

\footnotetext{
15 See Ap-Thomas, "Saul's Uncle." Cf. Edelman, King Saul, 55-56.

16 See $D N W S I$, vol. 1, 242: "word (subst?) of unknown meaning."

17 See Biran and Naveh, "An Aramaic Stele Fragment”; eidem, “The Tel Dan Inscription."

18 Cf., e.g., Athas, The Tel Dan Inscription.

19 See Garbini, "Liscrizione aramaica”; Lemche, "'House of David."

$20 \quad$ See Lemaire, "'House of David' Restored," 33; idem, "La dynastie Davidique."

21 Some scholars have accepted it (see, e.g., Langlois, "The Kings, the City and the House of David"), while others rejected it (see, e.g., Mykytiuk, Identifying Biblical Persons, 265-273).

22 See Finkelstein, Na'aman and Römer, "Restoring Line 31."
} 
Instead, they proposed to read it as $b l k$, known in the Bible as the legendary Moabite ruler (Balak), mentioned in Numbers 22-24.

Despite the doubts regarding the Tel Dan stele, I tend to accept the authenticity of its inscription, unearthed during controlled archaeological excavations. As to the inscription on the Mesha stele, I think it is impossible to determine its correct reading. At any event, I would refrain from citing these inscriptions as extra-biblical sources to prove the historicity of the biblical David. Accepting the inscriptions as genuine and approving the suggested readings as "House of David" is insufficient, in my view, to claim that these texts bring a decisive proof of the historicity of David.

Moreover, if we accept the authenticity of both objects dated to the ninth century BCE (i.e., the references to the "House of David" in the Aramaic inscription on the Tel Dan stele and the Moabite one on the Mesha stele) prove at most the existence - at the time when the inscriptions were written - of a dynasty claiming to be David's descendants. Accordingly, the historicity and existence of the Davidic dynasty may be sustained safely. Nonetheless, these references afford no proof of the historicity of the alleged founder of the ruling family in Judah who might have been a purely mythical figure. ${ }^{23}$

Studies of the etymology of the name "David," as well as extra-biblical examples of its occurrence, result from a continuing effort to establish the historical credibility of the Davidic tradition, of which the Bible is the only source. As we have seen above, extra-biblical sources attest to nothing more than the existence in the ninth century вСЕ of a ruling family claiming to be descendants of a certain $d w d$.

To sum up these two sections, in the discussions about the origins and etymology of the name $d w d$, three interpretations prevail. The first one derives the name "David" from a common noun, denoting the function of a military leader, or of a cultic functionary. Accordingly, it attempts to interpret David's name as one coined from an honorific title. ${ }^{24}$ The second hypothesis emphasises the relationship between the name "David" and the main meaning of the root $d w d$ - "to be beloved" - suggesting its derivation from divine epithets, or even from the proper name of a deity. The third way of explaining the origin of David's name - rarely expressed overtly, but implicitly present in the

23 Such was the case with the House of Piast, the first historical dynasty in Poland, whose founder - "Piast the Wheelwright," remains a legendary figure. Cf. also ancient Greek aristocratic families (e.g., the Alcmaeonidae in Athens), who claimed to be descendants of the mythical heroes.

Cf., e.g., Howard, "David (person)," 41. 
scholarship - accepts its unusual form and points to its unknown etymology. In the first two cases, scholars try to combine the etymological argument with historical reasoning, e.g., by asking whether the name of the historical David was a title or whether it was a name with a particular meaning.

As noted above, these explanations seem inconclusive. Paradoxically, the third interpretation, which does not offer any specific etymology for David's name and abstains from any possible epigraphical parallels, may offer the strongest argument in favour of the historicity of David. If a biblical hero credited as the founder of the ruling family, had been invented, in all likelihood he would have received at the very least a telling name. Such is the case with Solomon, whose historicity is much more doubtful. The use of telling names in the Hebrew Bible is common enough (e.g., Adam, Eve, Elijah) to imagine the invention of a "good" name for the ruling dynasty's legendary founder. The fact that we are unable to ascribe any specific meaning to David's name strongly suggests that the name was not invented for the sake of the narrative, but belonged to a real figure.

Thus, paradoxically, with the less-typical name for the literary character and its less-apparent meaning, the historicity of the original person bearing this name appears more plausible. Accordingly, although the reasoning for the name's etymology is evidently weak and inconclusive, it provides an argument that weakens the hypothesis that David is a purely literary figure invented out of thin air.

\section{The Davidic Traditions/Tradition on David}

Recent scholarly literature related to the figure of David exhibits a clear paradigm shift, entailing a separation of the study of the historical David, and his attributed kingdom, from the literary corpus of biblical texts related to him. Trust in the historical value of the biblical narratives, i.e., belief in the existence of David and his kingdom, had been the dominant tendency in scholarship during most of the twentieth century. However, a methodological shift in the use of the Hebrew Bible as a historical source and critical scholars' challenges to the prevailing paradigm considerably changed the discourse. Questions about the biblical narrative's historicity, as well as efforts to anchor ancient Hebrew literature in the absolute chronology more accurately, changed the way in which the Davidic biblical tradition has been approached in most recent scholarly works. The character of David inspired many biblical writers, who depicted this figure according to the common imagery of their times. Yet, 
historians must face key questions related to the biblical traditions' historical value. Can we reconstruct the history of David, King David, and his kingdom, on the basis of biblical literature?

Many scholars accept the re-dating of most of the biblical narratives, no longer viewing the history written in the tenth or ninth centuries BCE the same way it was viewed a century ago. Despite differences in the actual dating of the text, or its Vorlage, scholars tend to accept the Scriptures' trustworthiness when it comes to David. ${ }^{25}$ Such a position, sometimes not expressed explicitly, is based on the belief in the truth of the Bible, i.e., the conviction that the biblical authors intended to describe the past as it really was. Following this paradigm of thinking, they presume that the biblical authors had access to old historical sources describing the actual historical past. In their opinion, these sources might have been of two kinds: either there were legends about spectacular historical events from the past, faithfully transmitted through the ages in oral form, or there were written sources originating near the time of the events related to the history of King David (such as royal inscriptions or court annals). In the case of the latter source type, the texts did not survive, they are not even referred to in later texts (the only exception may be the "Book of Jasher" [Heb. Sēper ha-yā̌sār], mentioned in 2 Samuel 1:18, the possible content and origin date of which are, unfortunately, unknown).

Such texts might have indeed existed, but as they did not survive, nor were they referred to in a way to allow for their definite identification, historians cannot assume that they ever existed, much less consider their possible content. Accordingly, historians usually regard traditions supposedly transmitted orally through the ages as unfounded, as no method exists to prove or disprove the role of earlier oral traditions that might have inspired the actual writers. On the grounds of objective historical enquiry, understood as scholarly executed research, it is impossible to determine which content was transmitted through such oral traditions. Therefore, even if one accepts the fact that the biblical authors used oral traditions, it is virtually impossible to cite the actual content of such traditions. In addition, presuming their trustworthiness in faithfully transmitting real events would be a serious methodological mistake.

The above notwithstanding, scholars tend to presuppose the existence of a faithful oral tradition behind the biblical narrative about the early monarchy. However, recent scholarship increasingly stresses the role of written sources and of the biblical authors' creativity, to the detriment of the one played by

25 Cf. Halpern, David's Secret Demons; McKenzie, King David; Finkelstein, Silberman, David and Solomon. 
possible oral stories of remote origins in time. ${ }^{26}$ Accordingly, the older hypothesis about popular legends transmitted orally ${ }^{27}$ gradually gave way to the image of highly sophisticated, skilful literati who wrote the biblical historiography. ${ }^{28}$ As such, the stories about David should not be considered faithful memories of the past, preserved and transmitted in the collective memory as folk tales, but rather as the result of a purposeful effort made by intellectuals using sources at their disposal, as well as sophisticated literary devices, to compose stories that would reflect their specific ideological agendas. ${ }^{29}$

In recent years, scholarship has also witnessed a growing division between the study of the historical David and that of the biblical Davidic tradition. The best example of this new "exclusive" approach is Joseph Blenkinsopp's book David Remembered from 2013. ${ }^{30}$ Blenkinsopp sums up the studies in which David is considered a purely literary figure, developed in different ways by biblical writers from different periods. ${ }^{31}$ In this way, late biblical texts are not viewed as historical sources for the historicity of David, but as forms of literary expression of their authors and of the times in which they were active.

Following Blenkinsopp, one may state that the biblical tradition of David allows for treating it as a separate literary phenomenon unrelated to the real, historical David. As such, the literary David cycle in the Hebrew Bible should be studied mostly as a source of knowledge about the biblical writers' imagery and their use of David for their current agendas and ideologies. This reasoning allows for diachronic research on the development of the literary representation of David without a direct relation to supposed historical events from, let's say, the tenth century вСЕ. This shift in approach to the biblical texts is hardly a novelty for historians, who have long tended to read ancient sources in the light of their original context. ${ }^{32}$ The tendency to avoid a straightforward, uncritical reading of ancient sources still remains an important methodological postulate within biblical scholarship and the so-called biblical archaeology.

The methodology stressing the importance of influence exerted by ideology and the realities of the time on the final texts presents enormous difficulties to historians trying to distil "real" events from these texts. Keeping in mind the time gap between the occurrence of events and the moment when biblical texts were written, it is reasonable to doubt such sources' historical value. However,

\footnotetext{
26 See Davies, Scribes and Schools; Davies and Römer (eds.), Writing the Bible.

27 See Gunkel, Legends of Genesis; idem, Die Urgeschichte Und Die Patriarchen.

28 Edelman (ed.), The Fabric of History; Unsok Ro (ed.), Story and History.

29 See Garbini, "Davide nella storiografia," 21.

30 See Blenkinsopp, David Remembered.

31 Cf. also Fröhlich (ed.), David in Cultural Memory.

32 Cf. Garbini, Mito e storia nella Bibbia, 111-137.
} 
this is not to say that every late text has little historical value because of its date of origin. Some late texts may preserve valuable, ancient information, and it is the historian's task to evaluate sources and verify whether a given text may or may not be used as a reliable source of knowledge about past events. ${ }^{33}$

That being said, one may conclude that in this particular case, historians have dealt with two different - though tightly interwoven - fields of research: (1) The history of literature aiming to study literary forms and processes of creation, using topoi, patterns and literary devices diachronically; and (2) The history of real events reconstructed on the basis of fragmented, assorted, distorted, sometimes invented and thus simply improper (i.e., unreliable) sources. The first research field has plenty of valuable sources. In the second research field, the number of truly reliable, "solid" sources is difficult to estimate. It is up to each and every historian to evaluate the biblical material as a possible source of information about the historical David, as well as events from his time. It is even more demanding, as there is not a single extra-biblical source related to the historical David.

\section{The Davidic Narratives}

\subsection{Ancient Near Eastern and Greek Influences}

The biblical narratives on David in 1-2 Samuel have been studied extensively and cannot be addressed systematically here. Scholars have pointed out the unparalleled structure of the David narrative, which can be compared to that of a novel. In the quest for possible analogies between the themes in 1-2 Samuel and other ancient texts, some similarities have been brought to scholarly attention and highlighted. In an article from 1975, Harry A. Hoffner, Jr., ${ }^{34}$ postulates the existence of an ancient literary genre called "apology," examples of which he found in Hittite texts. This kind of literature supposedly influenced the biblical authors who described David in ways that resembled the one in which the Hittite king Hattusili III had been presented (стн 81). ${ }^{35}$ The Hittite document from the thirteenth century BCE is evidently a propaganda text - an apologia that describes Hattusili's rise to power. It presents a kind of literary device that aims to justify the king's usurpation. The king, who commissioned

33 Cf. Niesiołowski-Spanò, "Review of E.A. Knauf, Ph. Guillaume."

34 See Hoffner, "Propaganda and Political Justification." Cf. also Hoffner, "Ancient Israel's Literary Heritage," esp. 183; Sung-Hee Yoon, The Question of the Beginning, 101-105.

35 See Laroche (ed.), Catalogue des textes hittites, 58-62. Related bibliography available at <https://www.hethport.uni-wuerzburg.de/hetkonk/hetkonk_abfrage.php?c=81>, accessed 6 October 2018. 
the text, had no rightful claim to the throne and therefore needed propaganda to explain the legitimacy of his rule. Hence, the usurper enlists divine will to justify his claim. Peter Kyle McCarter use this analogy to hypothesise the David story's early origins. ${ }^{36}$

At first glance, the David narrative presents a close analogy, but it is uncertain whether the literary device featuring divine will as the usurper's justification to claim the throne was borrowed directly. In the case of every usurpation, the ruler needs a way to convince sceptics of the legality of his rule, and divine will is certainly the best way to explain an unusual circumstance of his rise to power. Thus, a similar usage of apologia in two distinct literary texts, as a way to explain rights to a throne, does not necessarily indicate a straightforward dependence on the Hittite document by the biblical narrative. This observation accords with the prevailing view in recent scholarship that the David narratives in 1-2 Samuel should be dated to the Second Temple Period, or more precisely, to the Persian Period.

Scholars pointing to possible Greek influences on the Hebrew Bible narratives make a different case, ${ }^{37}$ in which analogies are not limited to the general literary genre (as in the case of the propagandistic context of the so-called apologia of Hattusili III and David). Comparing Greek literature with biblical narratives, they seek parallels in literary threads, descriptions of individual scenes, their sequences and the very structure of analysed texts. In this context, the following scholars should be mentioned: Martin West, ${ }^{38}$ Flemming A.J. Nielsen, ${ }^{39}$ Jan-Wim Wesselius, ${ }^{40}$ Philippe Wajdenbaum, ${ }^{41}$ and Bruce Louden. ${ }^{42}$

Martin West presents a wide range of analogies between Greek and Near Eastern texts, suggesting that there was an Oriental influence on Greek authors. ${ }^{43}$ Although not all analogies necessarily testify to definite Oriental borrowings by the Greek authors, it is the case where the Hebrew Bible is concerned. To say the least, instances of literary similarities exist between

36 See Kyle McCarter, “The Apology of David.” Cf. also Hoffner, “A Hittite Analogue.”; Knapp, Royal Apologetic.

37 The comparison of Greek and biblical literatures has a long tradition. See e.g., Astour, Hellenosemitica; Brown, Israel and Hellas; Burkert, The Orientalising Revolution; Gordon, "Homer and Bible," 43-108; idem, The Common Background. Some preliminary observations about the possible relations between Greek and biblical historiography can be found in Niesiołowski-Spanò, "Athens and Jerusalem."

38 See West, The East Face of Helicon.

39 See Nielsen, The Tragedy in History.

40 See Wesselius, The Origin of the History of Israel, esp. 104-163.

41 See Wajdenbaum, Argonauts of the Desert. Cf. also Louden, Greek Myth and the Bible.

42 See Louden, Greek Myth and the Bible.

43 Cf. esp. Brown, Israel and Hellas. 
Greek literary works and the Hebrew Bible in which the source of the influence (if one accepts the idea that the similarities are not accidental) cannot be taken for granted. ${ }^{44}$ Some examples may be instructive, e.g., deep sleep sent by a divinity (Iliad $24.443-446$ and 1 Samuel $26: 12)^{45}$ or the structure of duels (Iliad 7.67-272 and 1 Samuel 17). ${ }^{46}$ Similarities between the David narrative and Homer's Iliad are also found in the Jonathan-David and Patroclus-Achilles relationships, respectively.

Philippe Wajdenbaum follows the same route in tracing narrative parallels between Greek and Hebrew literatures. The cases that Wajdenbaum analysed widen the possible range of Greek influence on the David narrative considerably: David and Jonathan in 1 Samuel 14:8-12 and Hdt V 1; 1 Samuel 14:13-15 and Iliad 10.470-505, 520-525, and especially 1 Samuel 14:14 and Iliad 10.350-355; the description of Goliath in 1 Samuel 17:43-47 and Iliad 13.825-830; 1 Samuel 17:48-49 and Iliad 16.570-575, 735-745; Saul's madness in 1 Samuel 18:10-11, 19:4-6, 9-10 and Hdt III 33, 36, as well as 1 Samuel 17:55-58 and Hdt VIII 9o; the night incursion in 1 Samuel 26:5-12 and Iliad 24.440-245, 10.150-155; the Witch of En-Dor in 1 Samuel 28:8-14, 21-25 and The Odyssey 10.315-380; analogies in the description of Ajax and Saul in 1 Samuel 31:3-6 and Sophocles' Ajax 815-86o as well as 2 Samuel 2:18-23 and Iliad 6.220-230, 16.595-599, 818-822; 2 Samuel 2:28 and Iliad 18.230-840; 2 Samuel 3:8 and Iliad 1.220-225; Abner's funeral in 2 Samuel $3: 31-36$ and the analogy in Iliad $23.120-15$ o, and especially Iliad $19 \cdot 315^{-} 320$.

In contrast with Martin West's and Philippe Wajdenbaum's studies of analogies in individual micro-narratives, Jan-Wim Wesselius and Flemming Nielsen maintain that entire large-scale narrative structures in the Hebrew Bible are based on the original Greek patterns provided by Herodotus' Histories. ${ }^{47}$

Possible Greek influence on the Hebrew Bible undoubtedly deserves further study, especially in the historical, diachronic context. Nevertheless, it is insufficient merely to point to literary parallels, and to hypothesize on this basis direct borrowing or mutual inspiration. Indicating possible literary analogies should go in tandem with reconstructing a plausible historical context for the process of cross-cultural interchanges. Possible and plausible time and place of contact between people who might have been involved in intellectual

\footnotetext{
44 Cf. Niesiołowski-Spanò, "Biblical Prophet Amos."

45 See West, The East Face of Helicon, 182.

46 See West, The East Face of Helicon, 214. Cf. ibidem, 44-45 on antiphonal and responsorial singing in the narrative on David, e.g., in 1 Samuel 18:7. Cf. Louden, Greek Myth and the Bible, 112.

See Nielsen, The Tragedy in History; Wesselius, The Origin of the History of Israel, 104-163.
} 
relationships and responsible for transfers of ideas, should be traced. ${ }^{48}$ The cumulative effect of West's, Wesselius' and Wajdenbaum's studies strengthens the hypothesis that the origin of large parts of the biblical Davidic narrative can be dated to the Second Temple Period. Furthermore, the possible impact of the Homeric epic texts on the Hebrew Bible might suggest an even earlier dating, while the suggested relationship between Herodotus' Histories and biblical stories might point to the end of the fifth century ВСЕ, at the earliest.

Yet, if one accepts the claim of possible influence of ancient Greek literature on the Hebrew Bible, including large parts of the narratives about David, the dating of the origin of this biblical literature should be reassessed accordingly. Current knowledge about the cultural setting in the province of Yehud in the Persian and early Hellenistic periods is of crucial importance. The possibility that Jewish literati from Yehud entered into contact with representatives of the Greek elites of the time, or at least people fluent in Greek literature, during the Persian period is rather unlikely (or, at least there are no direct sources pointing to such contacts). The situation changes significantly in the third and second centuries BCE, when Greek culture, including its educational system (which included Homer and Herodotus), appears in close proximity to Yehud, or even within the borders of the Jewish province. ${ }^{49}$ From this perspective, a Hellenistic origin for the narratives about David seems more plausible. ${ }^{50}$

Nonetheless, it should be noted that a possible late dating of the biblical narrative, does not, per se, diminish the text's value as a historical source. The text written in the third or second century вСE may contain a lot of valuable historical information. Accordingly, the date of origin should not be the main factor in accepting or rejecting the historical value of a narrative.

\subsection{Atypical Literary Motifs}

In the so-called Deuteronomistic account of David in 1-2 Samuel, a few main themes, narrative threads or aspects of the main plot can be singled out. For example the story of David is woven into the Saul narrative in order to support David's right to the throne. Thus it is evident that the Deuteronomistic account relies on two (or more) distinct traditions. The differences between them are apparent in the descriptions of David entering Saul's entourage (1 Samuel 16:22-23; 17:31; 17:55-58;18:2), Saul's envy of David's military successes

48 On theoretical studies on the "contact zones," see, e.g., Ulf, "Rethinking Cultural Contacts," 81-132; Niesiołowski-Spanò, Goliath's Legacy, 178-181.

49 This already was proposed by Garbini, "Davide nella storiografia," 21-22; Thompson, The Bible in History, 200-210.

$5^{\circ}$ Cf. Gmirkin, Berossus and Genesis; idem, Plato and the Creation of the Hebrew Bible. 
(1 Samuel 18:6-9.14-16.28-30), Saul's attempts to kill David (1 Samuel 18:10-11; 19:9-10), and others. ${ }^{51}$ In these well-known cases, the biblical redactors did not try to harmonise the divergent accounts and left alternative versions next to one another, indicating that the final author of this narrative used older versions and incorporated them into his account. We cannot say anything more about the Ur-narratives that he had at his disposal.

Another narrative cluster deals with David as the monarch of Judah. It addresses certain topics normally related to kingship, e.g., military campaigns; numerous wives; royal patronage over a dynastic cult; providing resources for the cult; purchasing the land-plot for the future temple (2 Samuel 24:11-25); bringing the cult-object (i.e., the ark) to the royal seat (2 Samuel 6); and appointing priests for the royal cult (Zadok, Abiathar). These traditional motifs of the royal narrative are juxtaposed with themes atypical of the (usually laudatory) royal literature. The most striking examples of such atypical themes are those which, although unusual for royal literature, are common in the ancient Near East. For instance, David seems to be addicted to women, who are described not as pure objects of male cravings, but - in the broader narrative - as triggers of the king's sins. David is also represented as untruthful and breaking promises, not to mention that he is depicted as a notorious liar and serial killer. ${ }^{52}$

Another strikingly unusual topic for the royal narrative - in the monarchy's social setting - is the king's dependence on external authority, be it a prophet (1 Samuel 16:11-13) or the elders of Israel (2 Samuel 5:3). Similarly, the suggestion that David was involved in a close relationship with Jonathan - apparently implying a homosexual liaison - also does not fit the typical narrative that aims to praise the king and strengthen the royal dynasty's position. For both the authors and the target audience, all these topics make David less ideal a character, far from the image of the perfect monarch.

It is my contention that the very existence of the atypical motifs in David's biblical portrayal reveals the late origin of the narrative. ${ }^{53}$ It is hard to conceive of such a balanced, or nuanced and psychologically appealing narrative being created in the monarchical era, where the aim of such a text would have been to build and strengthen the kings' positions, especially when they claim to be David's pedigree. Neither do these atypical narrative motifs reflect old, orally transmitted legends, independent of the official royal propaganda. Therefore they should rather be considered late additions and purely literary inventions. This is the case of a literary creation, aiming to present the literary hero of the

$5^{1} \quad$ See Garbini, "Davide nella storiografia," 18; idem, Mito e storia nella Bibbia, 112.

$5^{2}$ See Halpern, David's Secret Demons, 73-103.

53 Cf. Rückl, $A$ Sure House, who argues for the exilic period of the composition. 
narrative in a more balanced way and, as such, to deploy a more convincing portrayal of David.

Thus, the atypical aspects of the monarchical narrative do not attest to the historical background of the past, but to the writers' ideology. David is described as an un-ideal monarch, addicted to women, sinful and often weak, dependent on others, who may be characterised as a king who squandered his divine blessing. The last phenomenon is particularly interesting because it may attest to the literary device that biblical authors used: the image of a hero, well-rooted in the tradition, cannot be entirely erased from the narrative, but it can easily be reshaped, and thanks to that, its portrait can be modelled anew. The literary King David is hardly the historical one. He is a kind of king that the late authors wanted to have in their narrative about the past. The less ideal the character of David was, the better for those who opposed the monarchy.

Further, another atypical motif appears in connection with David's role in the foundation of the cult in royal capitals. ${ }^{54}$ David's role in the cult, probably as one of its founders, is indicated in many biblical passages, e.g., those that suggest his skills as the composer, and/or author of the Book of Psalms. The tradition about David being the author of the liturgical songs links him to the cult. Despite this strong link, 1-2 Samuel does not attribute the foundation of the main royal sanctuary in the capital of Jerusalem to David (incidentally, neither is it stated that David founded the sanctuary in Hebron, his first capital). Failing to attribute the foundation of the royal sanctuary in the capital city to the "Great King," the dynasty's founder, constitutes another atypical tradition about David.

The ancient Near Eastern traditions provide numerous examples of texts formed around the "Great Kings," founders of dynasties, who are also represented as founders of sanctuaries and benefactors of the cult. One should expect the narrative about David to bring additional information about his efforts to build a temple for God. In this case, we have another example of a text focused not on describing the past, but on reshaping earlier traditions according to the biblical author's agenda. The writer tries to diminish David's role by not giving him credit for building the temple in Jerusalem, a natural duty of the founder of the dynasty. The explanation of the reasons why David cannot build the temple (2 Samuel 7), despite his long rule in Jerusalem, remains as unconvincing as the rest of David's sins. ${ }^{55}$ In this reworking of the David's story it is

54 Here, and above, I use the terms "royal," and "king" for convenience without any attempt to describe the real nature of rule during David's times (irrespective of whenever they were).

55 See Garbini, “Davide nella storiografia," 24, 29-31. 
suggested that because of divine will, David was not as great as other traditions suggest - at least with regard to the cult. ${ }^{56}$ This is not a result of the biblical author's historical reasoning, but of his desire to impose his own political and ideological agenda on the Davidic tradition.

Having said that, one may ask whether the writer could reshape the figure of David to such a great extent, and how strong the real notion of the historical David was at his time. Considering that the material in 1-2 Samuel presents a very atypical account of the great, royal founder, should we consider the entire narrative a pure fiction? It seems safe to assume that if, at the time when 1-2 Samuel was written, memories of the historical David were very vague, it was possible for the biblical author to present his version of the account, based on his own agenda. But if so, the historical credibility of all the texts would be weakened. Or perhaps this new version in 1-2 Samuel simply offers a one-sided polemic against another tradition (regardless of its historical value). ${ }^{57}$

All in all, it is safe to admit that the narrative in 1-2 Samuel presents an atypical account of the life of a great king, and as such is probably not the best source of knowledge on the historical David, but rather it offers a set of ideas about a mythical hero imposed by the biblical author on the narrative.

To sum up this section, it should be emphasised that the entire literary cycle on Saul, David and Solomon strongly demonstrates the way biblical authors' own agenda shapes the narrative, adapting accordingly whatever historical material may have been available to them. Although, at first glance, 1-2 Samuel looks like historiography, it should not be considered as such. This is not a historical account intending to present the past as it was, but a narrative trying to convince the audience to adopt a particular worldview by creating an imaginary past.

However, it is nevertheless plausible that this past's new shape was forged out of older sources - memories about real events (transmitted orally or in writings) - significantly remodelled and reshaped. It was much easier and more efficient to deprive David of some of his accomplishments than to erase him from the cultural memory. Hence, the Davidic narrative cannot be considered historiography in the proper sense of the word. Rather, it is a kind of historical novel in which some valuable old traces of information are interwoven into the fabric of a new literary composition. Accordingly, its purpose is not

$5^{6}$ Cf. with a similar feature in the Moses story, in Niesiołowski-Spanò, "The Broken Structure."

57 Garbini accepts the very existence of the memory about real David, in part preserved in polemical text, e.g., Chronicles. See Garbini, "Davide nella storiografia." 
to explain the past as it was, nor to keep the memory in its current form, but instead to convey the propagandistic agenda of its authors. ${ }^{58}$

How can we reconstruct the historical David in the light of the critical evaluation of sources presented above? No extra-biblical sources referring to David exist. Some sources merely attest to the memory of David as the founder of a dynasty in Judah. In addition, the most extensive narrative about David that does exist (in the Hebrew Bible) is predominantly a literary fiction. Even if beneath the current biblical account are hidden vestiges of older sources, it is hardly possible to trace them back. The narratives as we have them today convey the biblical authors' worldviews and therefore cannot be considered reliable historical sources, especially if interpreted literally. The biblical authors used the figure of David for their persuasive purposes, while the reason for writing Davidic narratives down was not historiographic. These texts played a role in intense debates about forms of self-government, the cult's role in society, and borders between the Jews and others - debates that dominated Jews' long history during the so-called Second Temple Period.

For all these reasons, the exhaustive literature referring to David in the Hebrew Bible should be considered novels, of no historical value. Even if historically "true" details are provided, the entire narrative is not valuable as historiography. Thus, one ought to conclude that no historical sources exist that would allow us to reconstruct the historical David. Large parts of the Hebrew Bible that feature the figure of David were evidently not written as a form of commemoration and preservation of memory, but as a new version of the past, created for political and/or ideological reasons. Hence, critical historians should refrain from any attempts to reconstruct on this basis the historical David. The only thing that can be done is to present the historical realities, or context in which $a$ historical David could have possibly lived. ${ }^{59}$

\section{5}

\section{Historical Realities of "Davidic Times" - a Reassessment}

In contrast to the more theoretical assessments presented above, below I would like to offer a much more subjective reconstruction of what can be learned from the sources at our disposal. As already noted, the Hebrew Bible does not offer a historically accurate narrative about David. However, it does contain a number of details that refer to actual historical realities. Digging into

$5^{8}$ The issue of biblical historiography has recently been addressed in: Niesiołowski-Spanò, "Why Was the Biblical History Written During the Persian Period?"

59

Cf. Pfoh, "A Hebrew Mafioso," 37-43. 
the text to extract and single out valuable information from the overall fictitious biblical narrative goes beyond the scholarly quest for an objective truth.

Historical reasoning on the basis of onomastics is always most uncertain. For example, we have seen how the etymology of the name David remains unclear. It may be an old name of which we do not have attestation before the mid-ninth century. Some scholars tried to link the historical David with the noun attested to in extra-biblical sources. For example, Giovanni Garbini posits that the biblical figure of David represents the embodiment of the functionary called dawid, attested to in the Mesha stele as the "viceroy" in the subordinated territory. ${ }^{60}$ Such a conjecture implies limiting the timeframe of the historical David to the first half of the ninth century BCE, or up to ca. 830 BCE at the latest, when Tell es-Safi (biblical Gath) was destroyed. ${ }^{61}$ In this case, the historical David should be interpreted as a result of the literary evolution of memory about the Israelite officer, called dawid, and if so, the original figure called dawid should be dated to the rule of Omrides (ca. 882-853 ВСЕ). Nevertheless, this argument's weakness lies in the fact that there is no way to ascertain when the title dawid was coined. It may have been much earlier than the epigraphical attestation, e.g., provided that the kings of Gath had been calling their subordinates dawid. If so, the dates proposed by Garbini, i.e., from the time of Omri (са. 882-871 вСЕ) until the destruction of Gath (са. 83о вСЕ), remain purely speculative.

For those scholars who believe that the David narrative's most credible aspect is his name, no method exists to propose anything more detailed with regard to the original David's historical setting than the dating with terminus ante quem in the ninth century BCE. If one accepts the hypothesis that the character of David from the biblical narrative reflects an office, then - given the paucity of actual sources at our disposal - we cannot say much more than that.

The biblical text highlights the fact that David remained, for a while, under the rule of Achish, king of the City of Gath. This detail fits well into the larger scenario pointing to the Philistines' strong presence during Saul and David's era. This allows us to narrow the time frame in which to locate the time of David's activity. On this basis, one may say that the realities referred to in the Bible as "the time of David" could not have occurred earlier than ca. 1125 BCE (calculated as two generations after the settlement of the Philistines on the Levantine coast). ${ }^{62}$

6o See Garbini, Scrivere la storia d'Israele, 72-74.

61 See Maeir, "Integrating Micro- and Macro-Archaeology," 35-50.

62 See Niesiołowski-Spanò, Goliath's Legacy, 12-39. 
Moreover, if one accepts the detail about the City of Gath's role as the centerpoint, the date of the destruction of Tell es-Safi - identified with biblical Gath - during the time of Hazael from Damascus (ca. 83 о вСE) would offer a terminus ante quem for the time frame in question. However, assuming the authenticity of the details reported in the biblical narrative about the presence of the Philistine garrisons in Gibeon (1 Samuel 5:8. 11; 6:15), Bethlehem (2 Samuel 23:14) and Bet-Shean (1 Samuel 31:10), or perhaps even Jerusalem, ${ }^{63}$ it might be possible to narrow the suggested dating down by establishing the terminus ante quem to ca. 925 BCE, when the Egyptian army under Pharaoh Sheshonq marched through Palestine, bringing the local Philistine hegemony to an end. ${ }^{64}$ These two safe caesura determine the most likely time interval in which to place the historical reality of David behind the biblical narrative of David. Hardly anything more precise than that can be said, and the dates, ca. 1125-925 BCE, offer the most precise (possible) time frame for David's activity that a historian can risk proposing. ${ }^{65}$

Biblical chronology places David in the middle of this period. In this regard, there is no reason to reject the biblical chronology as one of the possible chronologies for the historical setting and absolute dating of the "historical" David's existence. Nonetheless, one should keep in mind that between the time fitting the reality of the "historical" David (i.e., the tenth century BCE) and the first firm attestation of the existence of the kingdom of Judah ruled by the Davidic dynasty lies a gap of more than a century. Therefore, either we should interpret the dynasty's Davidic lineage as the fictitious invention of Judah's rulers in the ninth century вСЕ, who sought to establish a link to their mythical founder; or we should admit that a real link between the dynasty's founder and his descendants hibernated for more than a century within the less important kingdom of Judah during a period when the kingdom of Israel politically dominated it. Both scenarios are possible, but it is impossible to prove which (if any) is correct.

To conclude, I am inclined to say that the historical realities reflected in the biblical account of the "historical" David as described in the biblical traditions point to the two centuries of the Philistine hegemony in the region (ca. 1125$925 \mathrm{BCE}$ ) as the most likely setting for his activity. Having a very limited number of written texts available in this period, in order to keep alive the memory

\footnotetext{
63 See Niesiołowski-Spanò, "The Philistines in Jerusalem?"

64 Niesiołowski-Spanò, Goliath's Legacy, 28-29, 37-38.

65 Therefore, the references about the kingdoms of Israel and Judah must be understood as anachronistic because the kingdom of Israel emerged in the central Hill Region only after the Sheshonq expedition, and Judah as the political entity emerged later.
} 
of the historical David the biblical authors made extensive use of orally transmitted materials. Thus, it is possible that David's historical era was closer to the end of the plausible timeframe suggested above, i.e., the tenth century вСЕ. If David was a historical person, he might have been the local leader of a small, Habiru-like group active in the Southern territories dominated by the Tribe of Benjamin and politically controlled by the Philistines from the City of Gath.

\section{Bibliography}

\section{Abbreviations}

ANET James B. Pritchard (ed.), Ancient Near Eastern Texts Relating to the Old Testament, vol. 1, Texts. Princeton: Princeton University Press, 1969.

$B D B \quad$ Francis Brown, Samuel Rolles Driver and Charles A. Briggs, A Hebrew and English Lexicon of the Old Testament. Boston, MA: Houghton, Mifflin and Company, 1906 (repr. 1997).

CAD I.J. Gelb, B. Landsberger, A.L. Oppenheim, E. Reiner (eds.), The Assyrian Dictionary, Chicago: 1956-2010.

CoS William Hallo, The Context of Scripture, vol. 1-3. Leiden - Boston: Brill, 2003 .

стH Emmanuel Laroche (ed.), Catalogue des textes hittites. Paris 1956-1958.

DNWSI Jacob Hoftijzer and Karel Jongeling, Dictionary of the North-West Semitic Inscriptions. vol. 1-2. Leiden: Brill, 1995.

$K A I^{2} \quad$ Herbert Donner, Wolfgan Röllig, Kanaanäische und Aramäische Inschriften, vol. 1. Wiesbaden: Harrassowitz, 2002.

\section{Secondary Literature}

Ap-Thomas, Dafydd R. "Saul's Uncle." Vetus Testamentum, 11 (1961), 241-245.

Astour, Michael C. Hellenosemitica. An Ethnic and Cultural Study in West Semitic Impact on Mycenaean Greece. Leiden: Brill, 1967.

Athas, George. The Tel Dan Inscription: A Reappraisal and a New Interpretation [Journal for the Study of the Old Testament Supplement, vol. 36o]. New York - London: De Gruyter, 2003 .

Barstad, Hans M. "Dod." In Dictionary of Deities and Demons in the Bible, edited by Karel van der Toorn, Bob Becking and Pieter W. van der Horst, 2nd ed. Leiden - Boston Koln, 1999, 259-262.

Biran, Avraham and Naveh, Joseph. "An Aramaic Stele Fragment from Tel Dan." Israel Exploration Journal, 43 (1993), 81-98.

Biran, Avraham and Naveh, Joseph. "The Tel Dan Inscription: A New Fragment." Israel Exploration Journal, 45 (1995), 1-18. 
Blenkinsopp, Joseph. David Remembered. Kingship and National Identity in Ancient Israel. Grand Rapids, MI - Cambridge: W.B. Eerdmans Publishing, 2013.

Brown, Francis, Driver, Samuel Rolles and Briggs, Charles A. A Hebrew and English Lexicon of the Old Testament. Boston, MA: Houghton, Mifflin and Company, 1906 (repr. 1997).

Brown, John Pairman. Israel and Hellas, vol. 1-3. Berlin: De Gruyter, 1995-2001.

Burkert, Walter. The Orientalizing Revolution: Near Eastern Influence on Greek Culture in the Early Archaic Age. Cambridge: Cambridge University Press, 1992.

Davies, Philip R. and Römer, Thomas (eds.). Writing the Bible: Scribes, Scribalism and Script. London - New York: Routledge Taylor \& Francis Group, 2015.

Davies, Philip R. Scribes and Schools: The Canonization of the Hebrew Scriptures. Louisville: Westminster John Knox Press, 1998.

Del Olmo Lete, Gregorio and Sanmartín, Joaquín. A Dictionary of the Ugaritic Language in the Alphabetic Tradition, Part 1. Leiden - Boston: Brill, 2003.

Dempster, Stephen G. "Dodavahu (person).” In Anchor Bible Dictionary, edited by David N. Freedman, vol. 2, 219-22o. New York: Doubleday, 1992.

Donner, Herbert and Röllig, Wolfgang. Kanaanäische und Aramäische Inschriften, vol. 1. Wiesbaden: Harrassowitz, 2002.

Edelman, Diana V. King Saul in the Historiography of Judah [Journal for the Study of the Old Testament Supplement, vol. 121]. Sheffield: Sheffield Academic Press, 1991.

Edelman, Diana V. (ed.). The Fabric of History. Text, Artifact and Israel's Past [Journal for the Study of the Old Testament Supplement, vol. 127]. Sheffield: Sheffield Academic Press, 1991.

Finkelstein, Israel and Silberman, Neil Asher. David and Solomon. In Search of the Bible's Sacred Kings and the Roots of the Western Tradition. New York: Free Press, 2006.

Finkelstein, Israel, Na'aman, Nadav and Römer, Thomas. "Restoring Line 31 in the Mesha Stele: The 'House of David' or Biblical Balak?.” Tel Aviv, 46 (2019), 3-11.

Fröhlich, Ida (ed.). David in Cultural Memory [Contributions to Biblical Exegesis \& Theology, vol. 93]. Leuven: Peeters, 2019.

Garbini, Giovanni. “L'iscrizione aramaica di Tel Dan." Rendiconti. Accademnia Nazionale dei Lincei, 9, no. 5 (1994), 461-471.

Garbini, Giovanni. "Davide nella storiografia dei libri storici (Sam-Re)." Ricerche StoricoBibliche, 7 , no. 1 (1995), 17-33.

Garbini, Giovanni. Mito e storia nella Bibbia. Brescia: Paideia, 2003.

Garbini, Giovanni. Scrivere la storia d'Israele. Brescia: Paideia, 2008.

Gmirkin, Russell. Berossus and Genesis, Manetho and Exodus: Hellenistics Histories and the Date of the Pentateuch [The Library of Hebrew Bible/Old Testament Studies, vol. 433]. London - New York: T\&T Clark, 2006.

Gmirkin, Russell. Plato and the Creation of the Hebrew Bible. New York: Routledge, 2017. 
Gordon, Cyrus Herzl. "Homer and Bible.The Origin and Character of East Mediterranean Literature." Hebrew Union College Annual, 26 (1955), 43-108.

Gordon, Cyrus Herzl. The Common Background of Greek and Hebrew Civilizations. New York: W.W. Norton and Co., 1965.

Gunkel, Herman. Legends of Genesis. Chicago: Open Court Pub. Co., 19o1; repr.: Altenmünster: Jazzybee Verlag, 2012.

Gunkel, Herman. Die Urgeschichte Und Die Patriarchen (Das Erste Buch Mosis): Übersetzt Und Erklärt Und Mit Einleitungen in Die Fünf Bücher Mosis Und in Die Sagen Des Ersten Buches Mosis Versehen. Göttingen: Vandenhoeck \& Ruprecht, 1921. Hallo, William. The Context of Scripture, vol. 1-3. Leiden - Boston: Brill, 2003.

Halpern, Baruch. David's Secret Demons. Messiah, Murderer, Traitor, King. Grand Rapids, MI - Cambridge: W.B. Eerdmans Publishing, 2001.

Hoffner, Jr., Harry A. "A Hittite Analogue to the David and Goliath Contest of Champions?" Catholic Biblical Quarterly, 30, no. 2 (1968), 220-225.

Hoffner, Jr., Harry A. "Propaganda and Political Justification in Hittite Historiography." In Unity and Diversity: Essays in the History, Literature, and Religion of the Ancient Near East, edited by Hans Goedicke, Jimmy Jack McBee Roberts, 49-62. Baltimore London: Johns Hopkins University Press, 1975.

Hoffner, Jr., Harry A. “Ancient Israel's Literary Heritage Compared with Hittite Textual Data." In The Future of Biblical Archaeology; Reassessing Methodologies and Assumptions, edited by James K. Hoffmeier and Alan Millard, 176-192. Grand Rapids, MI: W.B. Eerdmans Publishing, 2004.

Hoftijzer, Jacob and Jongeling, Karel. Dictionary of the North-West Semitic Inscriptions. vol. 1-2. Leiden: Brill, 1995.

Howard, Jr., David M. “David (person).” In Anchor Bible Dictionary, edited by David N. Freedman, vol. 2, 41-49. New York: Doubleday, 1992.

Jackson, Kent P. "The Language of the Mesha Inscription." In Studies in the Mesha Inscription and Moab, edited by Andrew Dearman, 111-113. Atlanta: Scholars Press, 1989.

Kitchen, Kenneth A. On the Reliability of the Old Testament. Grand Rapids, MI: Eerdmans, 2003.

Knapp, Andrew. Royal Apologetic in the Ancient Near East. Atlanta: Society of Biblical Literature Press, 2015 .

Langlois, Michael. "The Kings, the City and the House of David on the Mesha Stele in Light of New Imaging Techniques." Semitica, 61 (2019), 23-47.

Laroche, Emmanuel (ed.). Catalogue des textes hittites [Revue hittite et asianique],

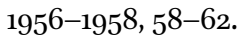

Lemaire, André. "La dynastie Davidique (byt $d w d$ ) dans deux inscriptions ouestsémitique du IXe s. av. J.-C.” Studi Epigrafici e Linguistici, 11 (1994), 17-19. 
Lemaire, André. “House of David' Restored in Moabite Inscription." BiblicalArchaeology Review, 20, no. 3 (1994), 33.

Lemche, Niels Peter "House of David': The Tel Dan Inscription(s)." In Jerusalem in Ancient History and Tradition, edited by Thomas L. Thompson, 46-67 [Journal for the Study of the Old Testament Supplement, vol. 381]. London - New York, 2003.

Louden, Bruce. Greek Myth and the Bible. London - New York: Routledge, 2019.

Maeir, Aren M. Integrating Micro- and Macro-Archaeology at a Multi-Period Site: Insights and Outcomes from Tell es-Safi/Gath. In Cyber-Archaeology and Grand Narratives: Digital Technology and Deep-Tim Perspectives on Culture Change in the Middle East, edited by Thomas E. Levy and Ian W.N. Jones, 35-50. Cham: Springer, 2017.

McCarter, Jr., Peter Kyle. “The Apology of David.” Journal of Biblical Literature 99, no. 4 (1980), 489-504.

McKenzie, Steven L. King David. A Biography. Oxford: Oxford University Press, 2002.

Mykytiuk, Lawrence J. Identifying Biblical Persons in Northwest Semitic Inscriptions of 1200-539 B.C.E. Atlanta: Society of Biblical Literature Press, 2004.

Nielsen, Flemming A.J. The Tragedy in History: Herodotus and the Deuteronomistic History, [The Library of Hebrew Bible/Old Testament Studies, vol. 251]. Sheffield: Sheffield Academic Press, 1997.

Niesiołowski-Spanò, Łukasz. "Biblical Prophet Amos - A Simple, Poor Shepherd From Judah?.” In Euergesias Charin. Studies Presented to Benedetto Bravo and Ewa Wipszycka by Their Disciples, edited by Tomasz Derda, Jakub Urbanik, Marek Węcowski, 211-217. Warsaw: Fundacja im. Rafała Taubenschlaga, 2002.

Niesiołowski-Spanò, Łukasz. "The Broken Structure of the Moses Story: Or, Moses and the Jerusalem Temple." Scandinavian Journal of the Old Testament, 23, no. 1 (2009), 23-37.

Niesiołowski-Spanò, Łukasz. "The Philistines in Jerusalem? The Use of Archaeological Data as the Ethnic Marker: The Case of the Philistines, Other 'Sea Peoples,' and Judah." In SOMA 2012. Identity and Connectivity: Proceedings of the 16th Symposium on Mediterranean Archaeology, Florence, Italy, 1-3 March 2012, edited by Luca Bombardieri, Anacleto D'Agostino, Guido Guarducci, Valentina Orsi, Stefano Valentini, 89-96 [BAR International Series S2581]. Oxford: Archaeopress, 2013.

Niesiołowski-Spanò, Łukasz. Goliath's Legacy. Philistines and Hebrews in Biblical Times [Philippika, vol. 83]. Wiesbaden: Harrassowitz Verlag, 2016.

Niesiołowski-Spanò, Łukasz. "Athens and Jerusalem, Again. The New Paradigm of the Jewish and Greek Intercultural Relationships?" In Awìlum ša ana la mašê - man who can not be forgotten. Studies in in Honor of Prof. Stefan Zawadzki presented on the Occasion of his 7oth Birthday, edited by Rafał Koliński, Jan Prostko-Prostyński, Witold Tyborowski, 161-169 [Alter Orient und Altes Testament, vol. 463]. Münster: Ugarit Verlag, 2018. 
Niesiołowski-Spanò, Łukasz. "Review of E.A. Knauf, Ph. Guillaume, A History of Biblical Israel. The Fate of the Tribes and Kingdoms from Merenptah to Bar Kochba, London 2016." Revue Biblique, 125 (2018), 277-282.

Niesiołowski-Spanò, Łukasz. "Why Was the Biblical History Written During the Persian Period? Persuasive Aspects of Biblical Historiography and its Political Context." In Collective Memory and Collective Identity: Case Studies in Deuteronomy and the Deuteronomistic History, edited by Johannes Unsok Ro, Diana Edelman, 353-376 [Beihefte zur Zeitschrift für die alttestamentliche Wissenschaft, vol. 534]. Berlin New York: de Gruyter, 2021.

Noonan, Benjamin J. Non-Semitic Loanwords in the Hebrew Bible. A Lexicon of Language Contact. University Park, PA: Eisenbrauns, 2019.

Pfoh, Emanuel. "A Hebrew Mafioso: Reading 1 Samuel 25 Anthropologically." Semitica et Classica: Revue internationale d'études orientales et méditerranéennes, 7 (2014), $37-43$.

Pritchard, James B. (ed.). Ancient Near Eastern Texts Relating to the Old Testament, vol. 1, Texts. Princeton: Princeton University Press, 1969.

Rückl, Jan. A Sure House: Studies on the Dynastic Promise to David in the Books of Samuel and Kings. Fribourg - Göttingen: Academic Press - Vandenhoeck \& Ruprecht, 2016.

Schley, Donald G. "Dodo (person)." In Anchor Bible Dictionary, edited by David N. Freedman, vol. 2, 22o. Yale: Yale University Press, 1992.

Tadmor, Hayim. "Historical Implications of the Correct Rendering of Akkadian dâku." Journal of Near Eastern Studies, 17 (1958), 129-141.

Thompson, Thomas L. The Bible in History. How Writers Create a Past. London:Jonathan Cape, 1999 .

Ulf, Christoph. "Rethinking Cultural Contacts." Ancient West \& East, 8 (2009), 81-132. Unsok Ro, Johannes (ed.). Story and History: The Kings of Israel and Judah in Context [Forschungen zum Alten Testament II, vol. 105]. Tübingen: Mohr Siebeck, 2019.

Wajdenbaum, Philippe. Argonauts of the Desert. Structural Analysis of the Hebrew Bible [Copenhagen International Seminar]. London - New York: Routledge, 2011.

Wesselius, Jan-Wim. The Origin of the History of Israel. Herodotus' Histories as Blueprint for the First Books of the Bible [Journal for the Study of the Old Testament Supplement, vol. 345]. Sheffield: Sheffield Academic Press, 2002.

West, Martin L. The East Face of Helicon. West Asiatic Elements in Greek Poetry. Oxford: Oxford University Press, 1997.

Yoon, Sung-Hee. The Question of the Beginning and the Ending of the So-Called History of David's Rise: A Methodological Reflection and Its Implications [Beihefte zur Zeitschrift für die alttestamentliche Wissenschaft, vol. 462]. Berlin: De Gruyter, 2014. 